Article

\title{
Salinosporamide A, a Marine-Derived Proteasome Inhibitor, Inhibits T Cell Activation through Regulating Proliferation and the Cell Cycle
}

\author{
Hyun-Su Lee and Gil-Saeng Jeong * \\ College of Pharmacy, Keimyung University, 1095 Dalgubeol-daero, Daegu 42601, Korea; hyunsu.lee@kmu.ac.kr \\ * Correspondence: gsjeong@kmu.ac.kr; Tel.: +82-53-580-6649; Fax: +82-53-580-6645
}

Academic Editor: Ryuichi Sakai

Received: 29 September 2020; Accepted: 28 October 2020; Published: 29 October 2020

check for updates

\begin{abstract}
The appropriate regulation of $\mathrm{T}$ cell activity under inflammatory conditions is crucial for maintaining immune homeostasis. Salinosporamide A discovered as a self-resistance product from the marine bacterium Salinospora tropica, has been used as a potent proteasome inhibitor (PI). Although PIs have been developed as novel therapeutics for autoimmune diseases, due to their immunosuppressive effect, whether salinosporamide A inhibits $\mathrm{T}$ cell activation remains unknown. The current study finds that salinosporamide A is not cytotoxic, but controls $\mathrm{T}$ cell proliferation. Results from our cell cycle arrest analysis revealed that salinosporamide A leads to cell cycle arrest and regulates the expression of cyclin-dependent kinases. Under activated conditions, salinosporamide A abrogated T cell activation by T cell receptor-mediated stimulation, in which the production of cytokines was inhibited by pretreatment with salinosporamide A. Furthermore, we demonstrated that the regulation of $\mathrm{T}$ cell activation by salinosporamide $\mathrm{A}$ is mediated by suppressing the MAPK pathway. Therefore, our results suggest that salinosporamide A effectively suppresses $\mathrm{T}$ cell activation through regulating $\mathrm{T}$ cell proliferation and the cell cycle and provides great insight into the development of novel therapeutics for autoimmune diseases or graft-versus-host disease.
\end{abstract}

Keywords: cell cycle; proteasome inhibitor; salinosporamide A; marine life-derived; T cell proliferation

\section{Introduction}

During the immune response, the proper regulation of $\mathrm{T}$ cells is pivotal for maintaining immunological homeostasis, because $\mathrm{T}$ cells link humoral immunity to adaptive immunity [1]. Therefore, several events related to $\mathrm{T}$ cell activation, including antigenic priming by antigen-presenting cells, activation, and differentiation into effector T cells, should be accurately controlled. Mounting evidence has demonstrated that excessive $\mathrm{T}$ cell activity causes a severe immune imbalance or an autoimmune response [2,3]. To control the immunological diseases induced by excessive $\mathrm{T}$ cell activation, immunosuppressive reagents have been used. Such agents are categorized into two groups: Inhibitors of pro-inflammatory cytokine production from activated T cells or apoptosis promoters for hazardous T cells.

$\mathrm{T}$ cell proliferation is crucial for elevating the adaptive immune response, which is induced by $\mathrm{T}$ cell receptor (TCR)-mediated stimulation by co-stimulatory molecules [4,5]. T cell proliferation is initiated by entry into the cell cycle, which is strictly controlled by sequential changes in cyclin expression [6]. During the G1 phase, cyclin D is expressed as the first cyclin protein, while cyclin A is expressed at the entry to the $S$ phase [7]. Previously, it has been found that IL-2, a marker of early T cell activation, acts as the most potent growth factor for $\mathrm{T}$ cells [8]. Reduced $\mathrm{T}$ cell growth rates have been observed in the presence of neutralizing antibodies against IL-2, and T cells that are stimulated by antigenic 
engagement or mitogen activation have also shown proliferation upon treatment with IL-2 [9,10]. Several immunosuppressive reagents inhibit $\mathrm{T}$ cell proliferation in the presence of TCR-mediated stimulation or lead to cell cycle arrest [11,12]. Although various such reagents have been commercially developed, little is known about whether small molecules derived from natural products regulate $\mathrm{T}$ cell activation through proliferation pathways or cell cycle arrest.

Salinosporamide A, derived from marine bacteria, such as Salinospora tropica and Salinospora arenicola, is a potent proteasome inhibitor that was first discovered and structurally elucidated in 2003 [13] (Figure 1). Salinosporamide A has been shown to promote the apoptotic pathway in cancer cells at $35 \mathrm{nM}$ $(11 \mathrm{ng} / \mathrm{mL})$ by covalently altering the active site (threonine) of the $\beta$-subunit of the 20S proteasome [14]. Although various proteasome inhibitors have been found to inhibit cell proliferation by inducing cell cycle arrest, whether salinosporamide A has a regulatory effect on $\mathrm{T}$ cell activation has not yet been reported $[15,16]$. In the present study, we first found that treatment of T cells with salinosporamide A efficiently suppressed cell proliferation and promoted cell cycle arrest, in a dose-dependent manner. These inhibitory mechanisms result in the inhibition of T cell activity and the MAPK signaling pathway, following stimulation by anti-CD3 and CD28 antibodies.

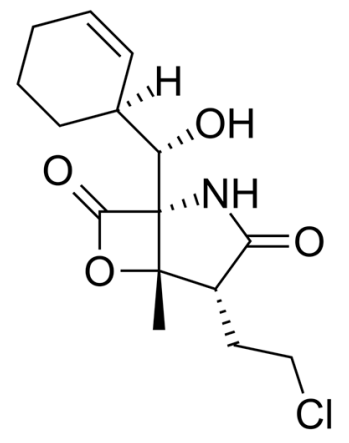

Figure 1. The chemical structure of salinosporamide A.

\section{Result}

\subsection{High Concentrations of Salinosporamide are Cytotoxic to T Cells and Leads to Apoptosis}

Since salinosporamide A has been reported to exhibit cytotoxicity in HCT-116 colon carcinoma at an $\mathrm{IC}_{50}$ of $11 \mathrm{ng} / \mathrm{mL}(35 \mathrm{nM})$, we first confirmed whether salinosporamide A is cytotoxic in Jurkat T cells in the presence of up to $40 \mathrm{nM}$ of salinosporamide A. Treatment with salinosporamide A induced cellular death in a dose-dependent manner $(<40 \mathrm{nM})$ (Figure $2 \mathrm{~A})$. To determine whether salinosporamide A promotes apoptosis in Jurkat T cells, AnnexinV and caspase3/7 expression levels were evaluated. As shown in Figure 2B,C, AnnexinV expression was significantly upregulated, but caspase3/7 expression was reduced in a dose-dependent manner. The results from the AnnexinV/propidium iodide apoptotic assay confirmed that high concentrations of salinosporamide A (up to $40 \mathrm{nM}$ ) lead to Jurkat T cell apoptosis. These data suggest that treatment with high concentrations of salinosporamide A (20 nM and $40 \mathrm{nM}$ ) is cytotoxic and induces apoptosis in Jurkat T cells, and this finding is highly consistent with that of a previous report [13]. 
A

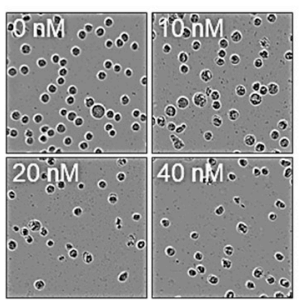

B

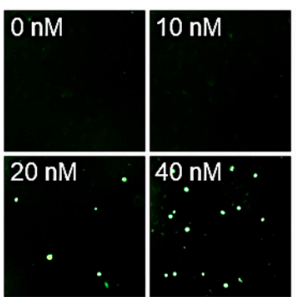

C

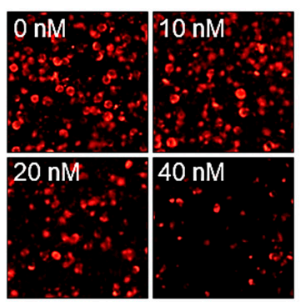

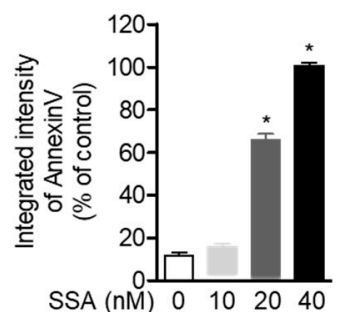
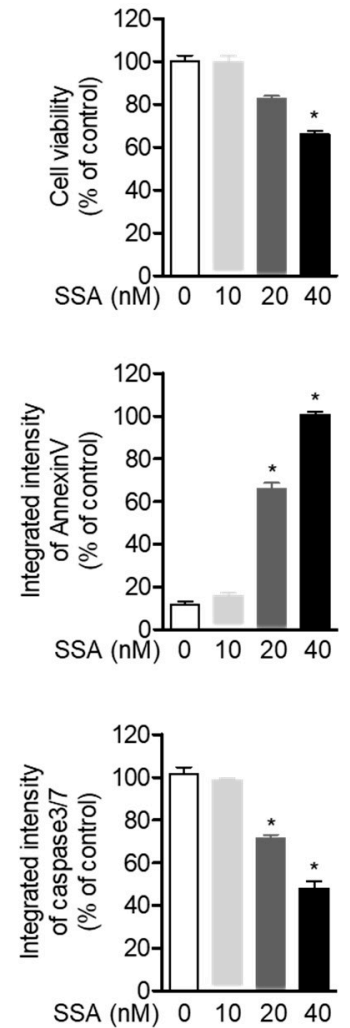

D
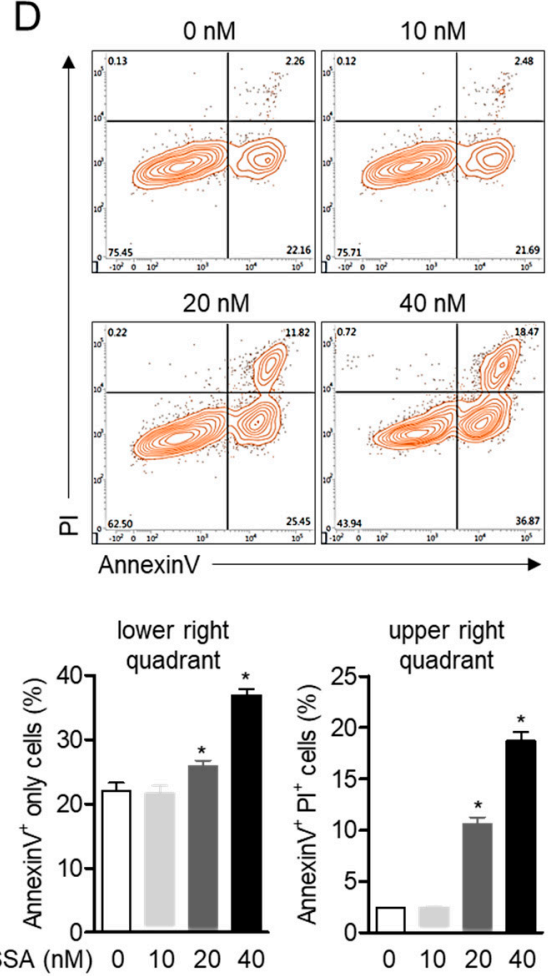

Figure 2. High concentrations of salinosporamide $\mathrm{A}$ are cytotoxic to $\mathrm{T}$ cells and leads to apoptosis. (A-C) DIC images (A), the expression of AnnexinV (B), or caspase3/7 (C) in Jurkat T cells obtained from the IncuCyte imaging system after incubation with the indicated concentration of salinosporamide A $(0-40 \mathrm{nM})$ for $24 \mathrm{~h}$. (D) The apoptotic population was identified by an AnnexinV/PI apoptosis assay, after incubation with the indicated concentration of salinosporamide A $(0-40 \mathrm{nM})$. The mean value of three experiments \pm SEM is presented. ${ }^{*} p<0.05$ between control cells.

\subsection{Treatment with $10 \mathrm{nM}$ Salinosporamide $A$ is not Cytotoxic to $T$ Cells}

Despite the fact that salinosporamide $\mathrm{A}$ is cytotoxic at concentrations of $20 \mathrm{nM}$ and $40 \mathrm{nM}$, which has been reported as the $\mathrm{IC}_{50}$ value of salinosporamide $\mathrm{A}$, we evaluated whether salinosporamide $\mathrm{A}$ was also cytotoxic to Jurkat $\mathrm{T}$ cells at concentrations lower than $20 \mathrm{nM}$. As shown in Figure 3A, Jurkat $\mathrm{T}$ cells incubated with 0.5 to $10 \mathrm{nM}$ salinosporamide A did not exhibit cell death after $24 \mathrm{~h}$. The expression levels of AnnexinV and caspase3/7 in Jurkat T cells treated with up to $10 \mathrm{nM}$ salinosporamide A also demonstrated that salinosporamide A does not cause Jurkat $\mathrm{T}$ cell apoptosis at these concentrations (Figure 3B,C). To address whether treatment with salinosporamide A affects primary T cells isolated from spleen and lymph nodes, MTT assay was performed after treatment with 2, 5, $10 \mathrm{nM}$ salinosporamide A of mouse T cells. Figure 3D revealed that treatment with salinosporamide A was not cytotoxic to primary T cells up to $10 \mathrm{nM}$ salinosporamide A. Furthermore, the expression levels of anti-apoptotic proteins, including Bcl-2, Caspase3, and Caspase7, did not change in the presence of salinosporamide A, after treatment for $24 \mathrm{~h}$ (Figure $3 \mathrm{E}$ ). These data indicate that treatment with up to $10 \mathrm{nM}$ salinosporamide A does not promote cell death and apoptosis in Jurkat $\mathrm{T}$ cells and mouse $\mathrm{T}$ cells. 
A

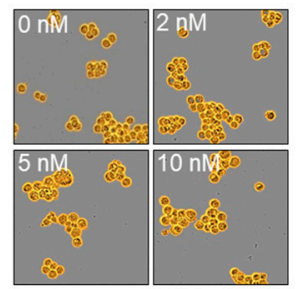

C

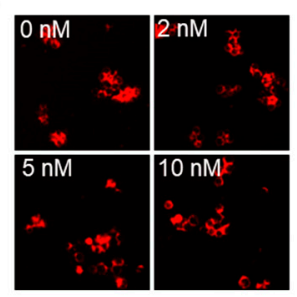

$\mathrm{E}$

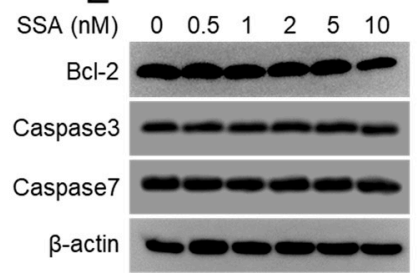

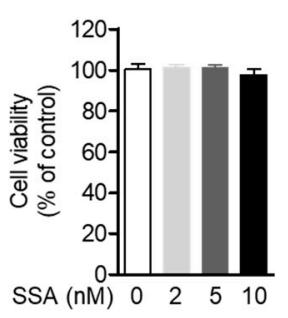

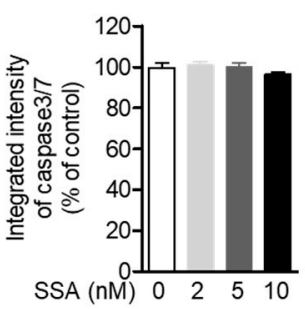

B
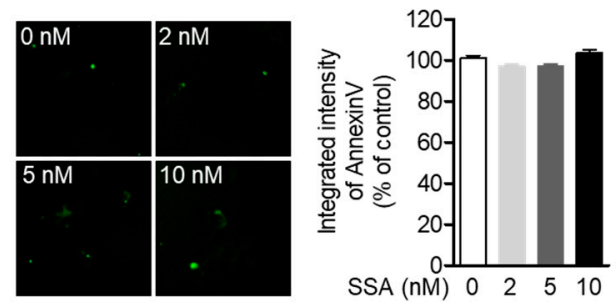

D

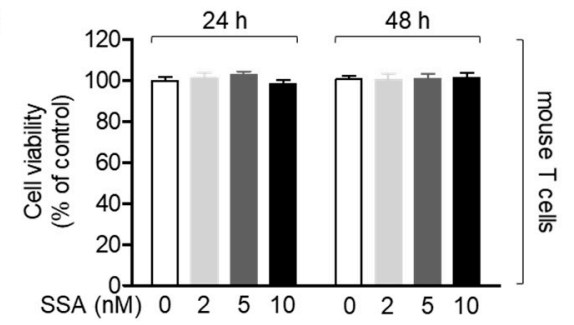

Figure 3. Treatment with $10 \mathrm{nM}$ salinosporamide $\mathrm{A}$ is not cytotoxic to $\mathrm{T}$ cells. (A-C) DIC images (A), the expression of AnnexinV (B), or caspase3/7 (C) in Jurkat T cells obtained from the IncuCyte imaging system after incubation with the indicated concentration of salinosporamide A (0-10 nM) for $24 \mathrm{~h}$. (D) Mouse $\mathrm{CD}^{+} \mathrm{T}$ cells were treated with the indicated concentration of salinosporamide $\mathrm{A}(0-10 \mathrm{nM})$ for $24 \mathrm{~h}$ or $48 \mathrm{~h}$. After incubation, cell viability was measured by MTT assay. (E) Expression levels of the indicated proteins were detected by western blot analysis of Jurkat $\mathrm{T}$ cells treated with the indicated concentration of salinosporamide A (0-10 nM) for $24 \mathrm{~h}$. The mean value of three experiments \pm SEM is presented.

\subsection{Treatment with $10 \mathrm{nM}$ Salinosporamide A Reduces $T$ Cell Proliferation}

To elucidate whether treatment with $10 \mathrm{nM}$ salinosporamide A affects $\mathrm{T}$ cell proliferation, a carboxyfluorescein succinimidyl ester (CFSE) proliferation assay was performed with Jurkat $\mathrm{T}$ cells incubated with $10 \mathrm{nM}$ salinosporamide A, by flow cytometry and IncuCyte imaging system. The suppressive effect of salinosporamide A on Jurkat $\mathrm{T}$ cell proliferation was determined by flow cytometry (Figure 4A), and suppression of CFSE-positive Jurkat $\mathrm{T}$ cells treated with salinosporamide A after $24 \mathrm{~h}$ was significantly downregulated, in a dose-dependent manner. Obtained microscopic images by IncuCyte imaging system also confirmed that treatment with salinosporamide A of Jurkat $\mathrm{T}$ cells reduced the attenuation of CFSE intensity after $24 \mathrm{~h}$ incubation compared to control cells (Figure 4B). Furthermore, the growth rate of Jurkat $\mathrm{T}$ cells were observed in the presence of salinosporamide A within $72 \mathrm{~h}$. Figure $4 \mathrm{C}$ revealed that treatment with $10 \mathrm{nM}$ salinosporamide A dramatically inhibits the growth rate of Jurkat $\mathrm{T}$ cells. These data suggest that salinosporamide $\mathrm{A}$ attenuates $\mathrm{T}$ cell proliferation, at concentrations of up to $10 \mathrm{nM}$. 

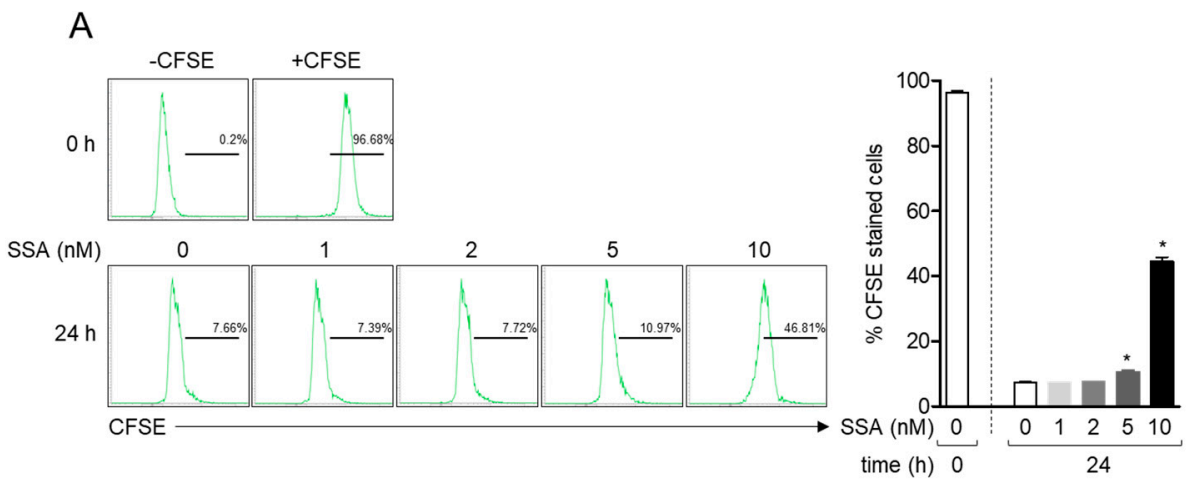

$\mathrm{B}$

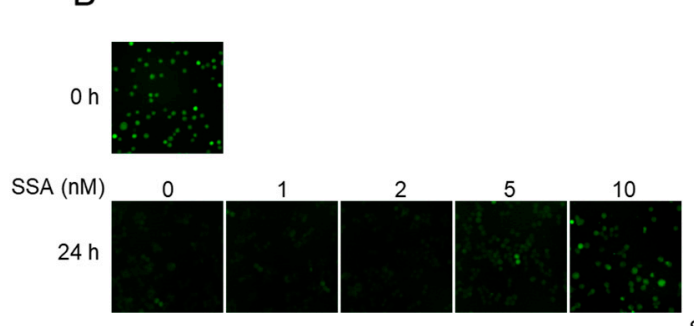

C

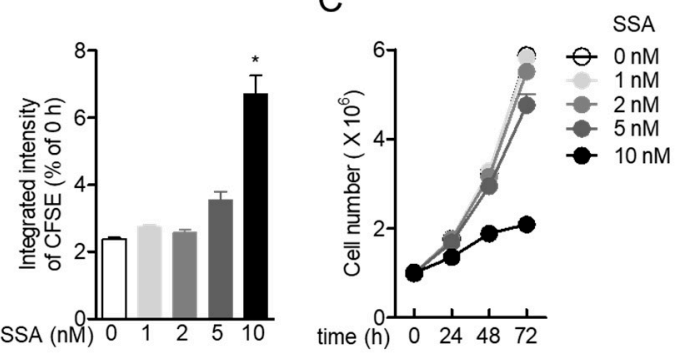

Figure 4. Treatment with $10 \mathrm{nM}$ salinosporamide A reduces $\mathrm{T}$ cell proliferation. (A, B) Jurkat $\mathrm{T}$ cells pre-stained with $1 \mu \mathrm{MCFSE}$ for $30 \mathrm{~min}$ were treated with the indicated concentration of salinosporamide A $(0-10 \mathrm{nM})$ for 24 . The percentage of CFSE-positive cells were measured by flow cytometry (A), and microscopic fluorescence images and integrated CFSE intensity were determined using an IncuCyte imaging system (B). The black line refers to CFSE-positive cells according to the negative control (-CFSE). (C) The growth rate of Jurkat $\mathrm{T}$ cells treated with the indicated concentration of salinosporamide $(0-10 \mathrm{nM})$ for $72 \mathrm{~h}$ was determined by counting the cell number every $24 \mathrm{~h}$. The mean value of three experiments \pm SEM is presented. ${ }^{*} p<0.05$ between control cells.

\subsection{Treatment with 10 nM Salinosporamide A Leads to Cell Cycle Arrest and Regulates Cyclin-Dependent} Kinase Expression in T Cells

T cell proliferation is tightly controlled by the expression of cyclins that regulate the cell cycle [17]. To evaluate the mechanism by which salinosporamide A dampens $T$ cell proliferation, the effect of this molecule on the cell cycle was determined. The result obtained from the cell cycle assay showed that the entry into G2/M phase in the cell cycle was significantly blocked by treatment with salinosporamide A. To confirm whether treatment with salinosporamide A affects the cyclin proteins, the expression levels of cyclinA, cyclinD1, and cyclinE were detected by western blotting. The expression of cyclinA and cyclinD1 was significantly downregulated by treatment with salinosporamide A, but comparable cyclinE expression was observed in the presence of salinosporamide A (Figure 5B). These data indicate that treatment with salinosporamide $\mathrm{A}$, at concentrations of up to $10 \mathrm{nM}$, efficiently arrests the cell cycle by blocking G2/M phase entry in Jurkat T cells. 
A
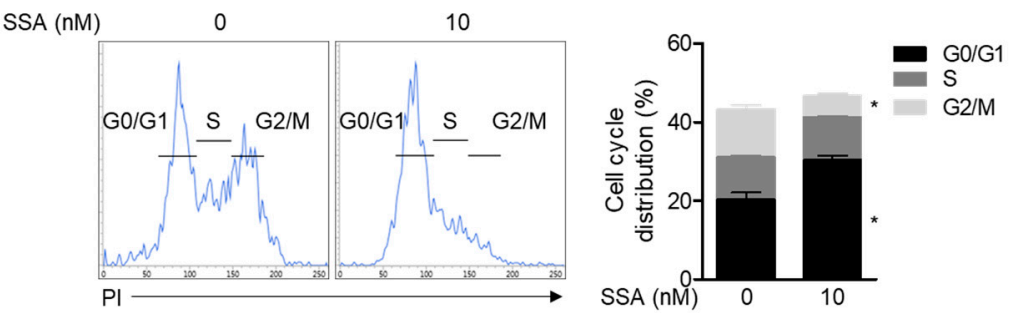

\section{B}

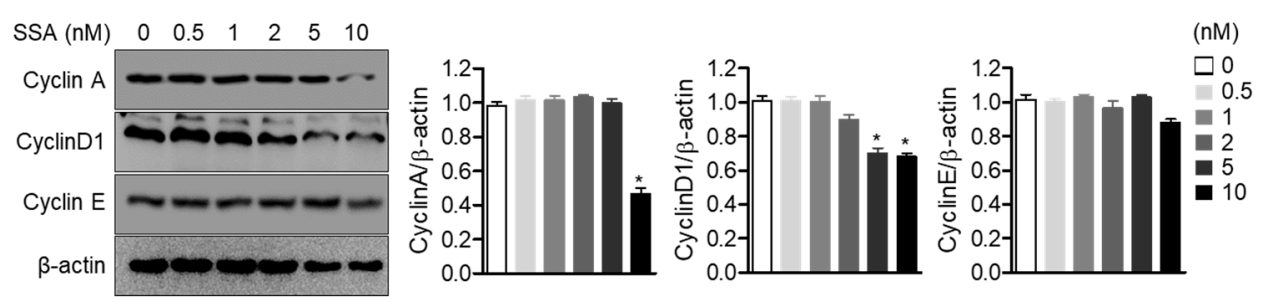

Figure 5. Treatment with $10 \mathrm{nM}$ salinosporamide A leads to cell cycle arrest and regulates cyclin-dependent kinase expression in T cells. (A) Cell cycle distribution of $\mathrm{T}$ cells treated with $10 \mathrm{nM}$ salinosporamide A for $24 \mathrm{~h}$ was determined by a PI staining assay using flow cytometry. (B) Expression levels of the indicated proteins were detected by western blot analysis of Jurkat T cells treated with the indicated concentration of salinosporamide A $(0-10 \mathrm{nM})$ for $24 \mathrm{~h}$. The mean value of three experiments \pm SEM is presented. ${ }^{*} p<0.05$ between control cells.

\subsection{Treatment with $10 \mathrm{nM}$ Salinosporamide A Inhibits T-Cell Activity Following TCR-Mediated} and PMA/A23187 Stimulation

Accumulating evidence has shown that $\mathrm{T}$ cell activity and pro-inflammatory cytokine production are highly associated with proliferation and the cell cycle. To elucidate whether incubation with salinosporamide A reduces T cell activity, the mRNA levels of $i l 2$ and ifng were measured in Jurkat $\mathrm{T}$ cells that were activated with anti-CD3/CD28 antibodies. Figure $6 \mathrm{~A}$ shows that pretreatment with salinosporamide A reduces pro-inflammatory cytokine mRNA levels in a dose-dependent manner. In particular, treatment with from $2 \mathrm{nM}$ of salinosporamide A reveals a suppressive effect on the expression of pro-inflammatory cytokines. The inhibition of $\mathrm{T}$ cell pro-inflammatory cytokine production by salinosporamide A was confirmed by time-dependent experiments (Figure 6B). To address whether salinosporamide A attenuates the expression of pro-inflammatory cytokines, il2 mRNA levels were detected from mouse T cells stimulated with PMA/A23187. Figure 6C revealed that pretreatment with salinosporamide A significantly downregulates mRNA level of il2 from stimulated mouse T cells with PMA/A23187 in a dose and time-dependent manner. These data suggest that treatment with salinosporamide A reduces the production of pro-inflammatory cytokines by Jurkat $\mathrm{T}$ cells and mouse $\mathrm{T}$ cells. 
A

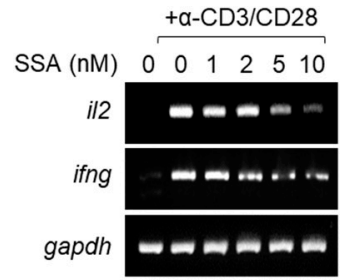

B

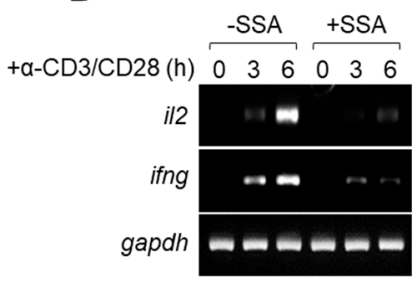

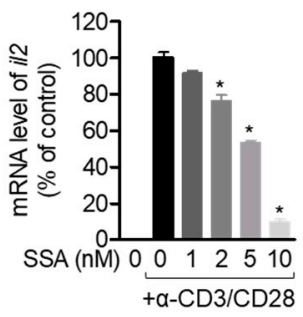

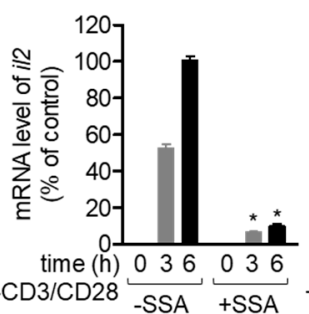

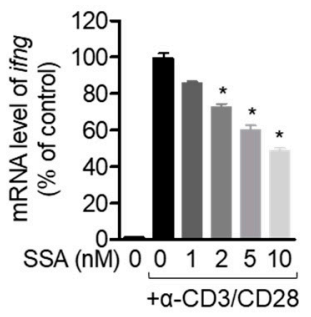

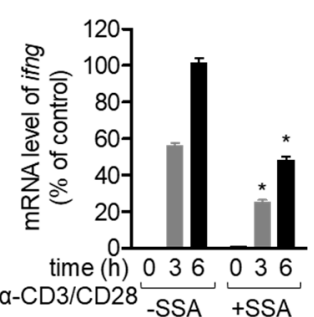

C
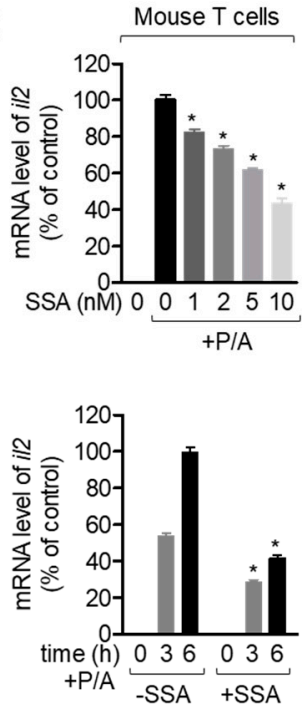

Figure 6. Treatment with $10 \mathrm{nM}$ salinosporamide A inhibits T-cell activity following TCR-mediated and PMA/A23187 stimulation. (A) Jurkat T cells pre-treated with the indicated concentration of salinosporamide A $(0-10 \mathrm{nM})$ for $1 \mathrm{~h}$ were stimulated with anti-CD3 $(20 \mu \mathrm{g} / \mathrm{mL}) / \mathrm{CD} 28(7 \mu \mathrm{g} / \mathrm{mL})$ antibodies for $6 \mathrm{~h}$. mRNA levels of $i l 2$ and ifng were measured by conventional and quantitative PCR. (B) Jurkat T cells pre-treated with the $10 \mathrm{nM}$ salinosporamide A for $1 \mathrm{~h}$ were stimulated with anti-CD3 $(20 \mu \mathrm{g} / \mathrm{mL}) / \mathrm{CD} 28(7 \mu \mathrm{g} / \mathrm{mL})$ antibodies for the indicated time $(0-6 \mathrm{~h})$. mRNA levels of $i 2$ and ifng were measured by conventional and quantitative PCR. (C) Mouse T cells pre-treated with the indicated concentration of salinosporamide A (0-10 nM) or $10 \mathrm{nM}$ salinosporamide A for $1 \mathrm{~h}$ were stimulated with PMA $(100 \mathrm{nM}) / \mathrm{A} 23187(1 \mu \mathrm{M})$ for $6 \mathrm{~h}$ or indicated time $(0-6 \mathrm{~h})$. After cells were harvested, the mRNA level of il 2 was determined by quantitative PCR. The mean value of three experiments \pm SEM is presented. ${ }^{*} p<0.05$ between control cells.

\subsection{Treatment with $10 \mathrm{nM}$ Salinosporamide A Dampens the MAPK Pathway in Activated T Cells}

$\mathrm{NF \kappa B}$ and MAPK have been elucidated as the major signaling pathways that promote $\mathrm{T}$ cell activation in Jurkat $T$ cells [18]. To check whether pretreatment with salinosporamide A suppresses $T$ cell activation through the NFKB and MAPK pathways, we first examined the translocation of p65 in activated $\mathrm{T}$ cells pretreated with salinosporamide A. Figure 7A shows that p65 translocation into the nucleus is partially blocked in Jurkat T cells pretreated with salinosporamide A. Phosphorylation and degradation of $\mathrm{I} \kappa \mathrm{B} \alpha$ were also observed (Figure $7 \mathrm{~A}$ ). To assess whether pretreatment with salinosporamide A influences the MAPK pathway in activated T cells, the phosphorylation levels of MAPK signaling molecules, including ERK, p38, and JNK, were detected by western blotting. Figure 7B shows that pretreatment with salinosporamide A efficiently suppressed the phosphorylation of MAPK signaling molecules, in a dose-dependent manner. These data indicate that treatment with up to $10 \mathrm{nM}$ salinosporamide inhibits T cell activation through suppressing NFKB and MAPK pathways in activated T cells. 
A
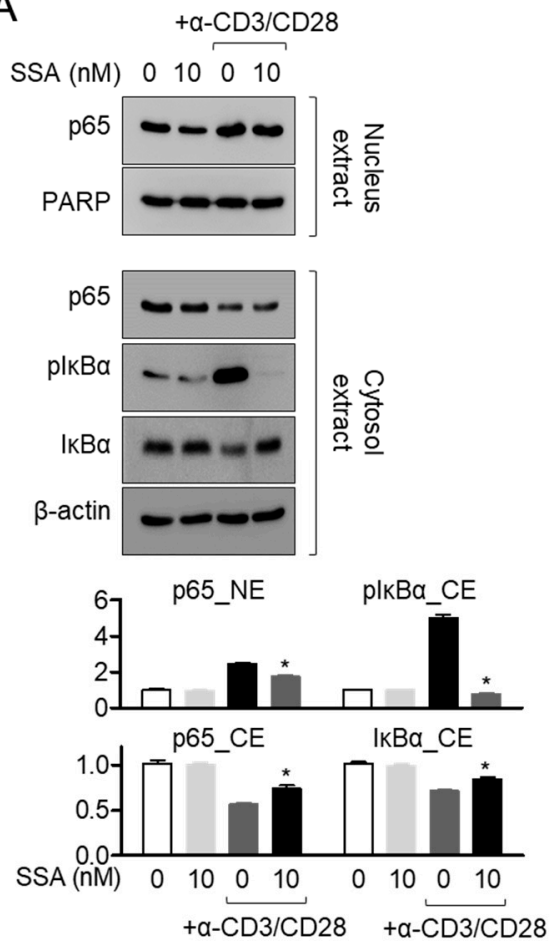

B

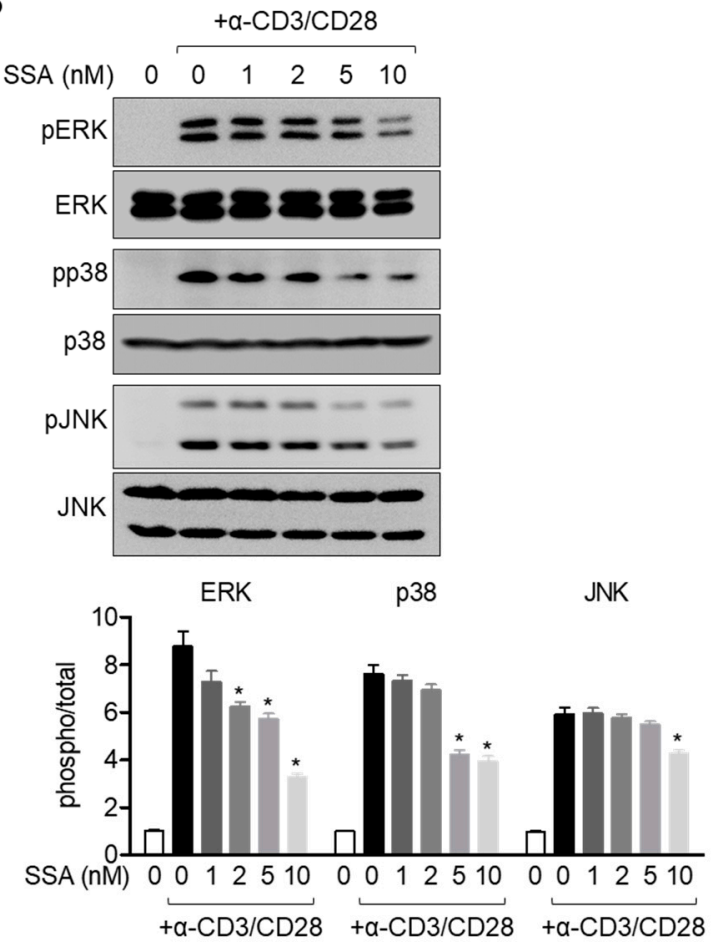

Figure 7. Treatment with $10 \mathrm{nM}$ salinosporamide A dampens the MAPK pathway in activated $\mathrm{T}$ cells. (A) Nuclear-translocated p65 and phosphorylated or degraded IKB $\alpha$ from activated Jurkat $T$ cells pre-treated with $10 \mathrm{nM}$ salinosporamide A were detected by western blot analysis. Separation of nucleus extract from the whole lysates was performed using the NE-PER kit. Nuclear protein was normalized to the expression of PARP, and cytosol protein was normalized to the expression of $\beta$-actin. (B) The phosphorylation levels of ERK, p38, and JNK from activated Jurkat T cells pre-treated with the indicated concentration of salinosporamide A were detected by western blot analysis. All phosphorylation levels were normalized to the total levels of each respective protein and presented in a bar graph. The mean value of three experiments \pm SEM is presented. ${ }^{*} p<0.05$ between control cells.

\section{Discussion}

In the present study, we demonstrated that salinosporamide A derived from marine life suppresses $\mathrm{T}$ cell activation by regulating $\mathrm{T}$ cell proliferation and entry into the cell cycle. First, it was clearly confirmed that salinosporamide A was not cytotoxic at concentrations below $10 \mathrm{nM}$ in Jurkat $\mathrm{T}$ cells and mouse T cells. Furthermore, it has been reported that treatment with salinosporamide A leads to apoptosis at a higher concentration of $35 \mathrm{nM}$. Treatment with $10 \mathrm{nM}$ salinosporamide A regulated the ability of Jurkat $\mathrm{T}$ cells to proliferate and enter into the G2/M phase of the cell cycle. The abrogated proliferation and cell cycle entry that were observed upon treatment with salinosporamide A were associated with a reduction in the production of pro-inflammatory cytokines, including IL-2 and IFN $\gamma$, by $\mathrm{T}$ cells in the presence of TCR-mediated stimulation of the NFKB and MAPK pathways.

$T$ cells proliferation and entry into the cell cycle are pivotal processes that occur after antigenic engagement with antigen-presenting cells in the early phase of inflammatory conditions [19]. Upon TCR-mediated stimulation, $\mathrm{T}$ cell proliferation and cell cycle entry are tightly controlled by several regulatory proteins that undergo proteasomal degradation $[20,21]$. A recent report has demonstrated that the activity of the proteasome is highly involved in the differentiation of $\mathrm{CD} 8^{+} \mathrm{T}$ cells into effector and memory T cells [22]. Due to the influence of proteasome inhibitors in regulating various $\mathrm{T}$ cell processes, finding the 'optimal concentration' that is effective without showing cytotoxicity is important in the pharmacological approach. In the current study, we first validated whether salinosporamide A leads to cytotoxicity in T cells, in a dose-dependent manner, and evaluated its 
pharmacological effects on T cell proliferation and entry into the cell cycle at a concentration of $10 \mathrm{nM}$. Although we observed that $40 \mathrm{nM}$ of salinosporamide A induces cellular apoptosis by performing an apoptosis assay [13], we also found that $10 \mathrm{nM}$ of salinosporamide A inhibits T cell activation by abrogating proliferation and entry into the cell cycle. Further studies should be conducted to determine whether $10 \mathrm{nM}$ salinosporamide A or less regulates the functions of $\mathrm{T}$ cells, such as differentiation into effector T cells or supervision of immune cells without cytotoxicity.

Several proteasome inhibitors have been developed as immunosuppressive reagents, due to their regulatory roles in antigen processing and presentation and in signaling cascades that regulate cellular functions and survival [23]. The biological functions of proteasome inhibitors have been recently identified in immune and cancer cells, and most proteasome inhibitors have been found to attenuate NFkB signaling $[24,25]$. A previous study has also evaluated a promising proteasome inhibitor as an immunosuppressive reagent in animal and clinical experiments and investigated transplant rejection using specific blocking antibodies and graft versus host disease [26]. Another trial investigated whether bortezomib attenuates autoimmune disorders, including rheumatoid arthritis and Sjögren's syndrome [27]. Interestingly, bortezomib has been shown to downregulate activated $\mathrm{T}$ cell proliferation and IL-2 production, similar to the findings of salinosporamide $\mathrm{A}$ in the current study $[28,29]$. We found that pretreatment with salinosporamide $\mathrm{A}$ inhibited $\mathrm{T}$ cell activation by repressing $\mathrm{T}$ cell proliferation and cell cycle entry. These results suggest that salinosporamide $\mathrm{A}$ can be developed as an immunosuppressive reagent to treat autoimmune disorders and transplant rejection.

\section{Materials and Methods}

\subsection{Cells}

Jurkat $\mathrm{T}$ cells were obtained from the Korean cell line bank (Seoul, Korea). Cells were cultured in RPMI medium (Welgene, Gyeongsan, Korea) supplemented with penicillin G (100 units $/ \mathrm{mL}$ ) and streptomycin $(100 \mu \mathrm{g} / \mathrm{mL}), 10 \%$ fetal bovine serum (FBS), and L-glutamine $(2 \mathrm{mM})$ at $37^{\circ} \mathrm{C}$ in a humidified incubator containing $5 \% \mathrm{CO}_{2}$ and $95 \%$ air.

\subsection{Reagents and Antibodies}

AnnexinV and caspase3/7 staining reagents for IncuCyte ${ }^{\circledR}$ cell imaging system were obtained from Essen bio (Ann Arbor, MI, USA). AnnexinV/PI apoptosis assay kit was purchased from BD Biosciences (San Diego, CA, USA). Anti-CD3 and anti-CD28 for stimulation were obtained from Bioxcell (West Lebanon, NH, USA). Salinosporamide A, MTT (1-(4,5-Dimethylthiazol-2-yl)3,5-diphenylformazan) powder, PMA (Phorbol 12-myristate 13-acetate), and A23187 was purchased from Sigma Chemical Co. (St. Louis, MO, USA). Carboxyfluorescein succinimidyl ester (CFSE) dye, ECL Western blotting detection reagents, and NE-PER Nuclear and Cytoplasmic Extraction Reagents Kit were obtained from Thermo Fisher Scientific (Waltham, MA, USA). PVDF membrane was obtained from Bio-Rad (Hercules, CA, USA). Anti-bcl-2, anti- $\beta$-actin, anti-cyclin A, anti-cyclin D1, and cyclin E antibodies were purchased from Santa Cruz Biotechnology (Dallas, TX, USA). Anti-caspase3, anti-caspase7, anti-p65, anti-PARP, anti-IKB $\alpha$, anti-ERK, anti-p38, anti-JNK, anti-phosphorylated IKB $\alpha$ (S32), anti-phosphorylated ERK (T202/Y204), anti-phosphorylated p38 (T180/Y182), and anti-phosphorylated JNK (T183/Y185) antibodies were obtained from cell signaling technology (Danvers, MA, USA).

\subsection{MTT Assay}

Cell viability was assessed by MTT assay. Jurkat $\mathrm{T}$ cells or mouse T cells $\left(1 \times 10^{4}\right.$ cells/well, 96 wells) were incubated with indicated concentrations $(0-40 \mathrm{nM})$ of salinosporamide A for $24 \mathrm{~h}$ at $37^{\circ} \mathrm{C}$. After incubation, MTT $(500 \mu \mathrm{g} / \mathrm{mL})$ was added to the incubated cells for $2 \mathrm{~h}$, and the supernatant was discarded for dissolving formazan crystal by adding $150 \mu \mathrm{L}$ of DMSO to each well. Plates were 
read at $540 \mathrm{~nm}$, and the cell viability was obtained by calculating normalized absorbance of each sample with absorbance from control cells. Cell viability was presented in $\%$ of control.

\subsection{Assessment of the Expressions of AnnexinV and Caspase3/7 by IncuCyte}

The expressions of AnnexinV or caspase3/7 after incubation of salinosporamide A were assessed by IncuCyte imaging system (Sartorius, Ann Arbor, MI, USA). Jurkat T cells $\left(1 \times 10^{4}\right.$ cells/well, 96 wells) were seeded and incubated with indicated concentrations of salinosporamide $(0-40 \mathrm{nM})$ for $24 \mathrm{~h}$. Before incubation, reagents for staining AnnexinV $(1 \mu \mathrm{M}$, green) and caspase $3 / 7(1 \mu \mathrm{M}$, red $)$ were added to the cell medium. Fluorescence from cells was acquired by IncuCyte imaging system, and the integrated intensity of AnnexinV or caspase3/7 were automatically calculated.

\subsection{AnnexinV/PI Apoptosis Assay}

The apoptotic population was evaluated by AnnexinV/PI apoptosis assay. Jurkat cells $\left(1 \times 10^{5}\right.$ cells/well, 24 wells $)$ treated with the indicated concentration of salinosporamide A $(0-40 \mathrm{nM})$ for $24 \mathrm{~h}$ were stained with AnnexinV and PI following manufacture's instruction. AnnexinV/PI-double positive population was presented in a bar graph.

\subsection{Isolation of Mouse T Cells}

Naïve C57BL/6 mice were sacrificed, and $\mathrm{CD} 4^{+} \mathrm{T}$ cells were isolated from the LNs and spleens by magnetic-activated cell sorting (MACS) separation (Miltenyi Biotec, Bergisch Gladbach, Germany). All experiments were approved by the Animal Care and Use Committee of the College of Pharmacy, Keimyung University (approval number: KM2020-007).

\subsection{Western Blot Assay}

Western blot assay was performed to detect the expression in protein level as a reference [30]. Jurkat cells were lysed in RIPA buffer for $30 \mathrm{~min}$ on ice and centrifuged at 14,000 rpm for $20 \mathrm{~min}$ at $4{ }^{\circ} \mathrm{C}$. For separation of nuclear extract from the whole lysate, cells were lysed with NE-PER Nuclear and Cytoplasmic Extraction Reagents (Thermo Fisher Scientific, Waltham, MA, USA) following the manufacturer's instructions. Approximately $30 \mu \mathrm{g}$ of the lysate was loaded on $8-12 \%$ SDS-PAGE gels for separation. Proteins were transferred on PVDF membranes (Bio-Rad, Hercules, CA, USA). Membranes were blocked with 5\% skim milk for $1 \mathrm{~h}$, rinsed with TBS containing $0.1 \%$ Tween 20 (TBS-T). Membranes were incubated with the indicated primary antibodies in 3\% skim milk in TBS-T overnight at $4{ }^{\circ} \mathrm{C}$. The next day, excess primary antibodies were removed with TBS-T, and then membranes were incubated with $0.1 \mu \mathrm{g} / \mathrm{mL}$ peroxidase-labeled secondary antibodies (against rabbit or mouse) for $1 \mathrm{~h}$. After three washes with TBS-T, bands were visualized with ECL Western blotting detection reagents (Thermo Fisher Scientific, Waltham, MA, USA) with an ImageQuant LAS 4000 (GE healthcare, Chicago, IL, USA). Representative images from three independent experiments are shown in figures, and all detected bands were normalized to $\beta$-actin for whole lysate or cytosol extracts and PARP for nucleus extracts.

\subsection{Proliferation Assay}

Jurkat $\mathrm{T}$ cells $\left(1 \times 10^{5}\right.$ cells/well, 24 wells $)$ pre-stained with $1 \mu \mathrm{M}$ CFSE for $30 \mathrm{~min}$ at $37^{\circ} \mathrm{C}$ were treated with the indicated concentration $(0-10 \mathrm{nM})$ for $24 \mathrm{~h}$. For obtaining images, cells were acquired by IncuCyte imaging system, and integrated intensity of CFSE from each well were automatically calculated. Cells were also acquired by flow cytometry for the determination of \% CFSE stained cells.

\subsection{Cell Cycle Arrest Assay}

Jurkat T cells $\left(1 \times 10^{5}\right.$ cells/well, 24 wells $)$ were incubated with $10 \mathrm{nM}$ salinosporamide A for 24 $\mathrm{h}$ and harvested for PI staining. Before staining with PI, cells were fixed with $70 \%$ cold ethanol for 
$1 \mathrm{~h}$. After three times wash with $1 \mathrm{X}$ cold PBS, cells were stained with $10 \mu \mathrm{g} / \mathrm{mL}$ PI for $30 \mathrm{~min}$. Stained cells were acquired by flow cytometry, and histogram observed were separated in G0/G1, S, and G2/M phase. Cell cycle distribution was presented in the \% G0/G1, S, and G2/M phase.

\subsection{Real-Time Quantitative PCR}

To measure mRNA levels of genes from cells, total RNA was isolated using TRIZOL reagent (JBI, Korea), and reverse transcription was performed using RT PreMix. Primers used for each gene were as follows (forward and reverse primers, respectively): human il2, 5'-CAC GTC TTG CAC TTG TCA C-3' and 5'-CCT TCT TGG GCA TGT AAA ACT-3'; human ifng, 5' ${ }^{\prime}$-TGA CCA GAG CAT CCA AAA GA-3' and 5'-CTC TTC GAC CTC GAA ACA GC-3'; human gapdh, 5' -CGG AGT CAA CGG ATT TGG TCG TAT- $3^{\prime}$ and $5^{\prime}$-AGC CTT CTC CAT GGT GGT GAA GAC- $3^{\prime}$; mouse $i l 2,5^{\prime}$-TGA GCA GGA TGG AGA ATT ACA GG-3' and 5'-GTC CAA GTT CAT CTT CTA GGC AC-3'; mouse gapdh, $5^{\prime}$-CGG AGT CAA CGG ATT TGG TCG TAT- $3^{\prime}$ and $5^{\prime}$-AGC CTT CTC CAT GGT GGT GAA GAC-3' PCR conditions were as follows: Forty cycles of denaturation at $94{ }^{\circ} \mathrm{C}$ for $30 \mathrm{~s}$, annealing at $60^{\circ} \mathrm{C}$ for $20 \mathrm{~s}$, and extension at $72{ }^{\circ} \mathrm{C}$ for $40 \mathrm{~s}$; followed by denaturation at $72{ }^{\circ} \mathrm{C}$ for $7 \mathrm{~min}$. For quantitative real-time PCR analysis, DNA Engine Opticon 1 continuous fluorescence detection system (MJ Research, Waltham, MA, USA) with SYBR Premix Ex Taq (Takara, Japan) was used. The total reaction volume was $10 \mu \mathrm{L}$. It contained $1 \mu \mathrm{L}$ of cDNA/control and gene-specific primers. Each PCR reaction was performed using the following conditions: $94{ }^{\circ} \mathrm{C} 30 \mathrm{~s}, 60{ }^{\circ} \mathrm{C} 30 \mathrm{~s}, 72{ }^{\circ} \mathrm{C} 30 \mathrm{~s}$, and the plate read (detection of fluorescent product) for 40 cycles followed by $7 \mathrm{~min}$ of extension at $72{ }^{\circ} \mathrm{C}$. Melting curve analysis was performed to characterize the dsDNA product by slowly increasing the temperature $\left(0.2^{\circ} \mathrm{C} / \mathrm{s}\right)$ from 65 ${ }^{\circ} \mathrm{C}$ to $95^{\circ} \mathrm{C}$ with fluorescence data collected at $0.2{ }^{\circ} \mathrm{C}$ intervals. mRNA levels of inflammatory cytokines normalized to gapdh were expressed as fold changes relative to those of untreated controls. The fold change in gene expression was calculated using the following equation: Fold change $=2-\Delta \Delta \mathrm{CT}$, where $\Delta \Delta \mathrm{CT}=(\mathrm{CT}$ Target $-\mathrm{CT}$ gapdh $)$ at time $\mathrm{x}-(\mathrm{CT}$ Target $-\mathrm{CT}$ gapdh $)$ at time $0 \mathrm{~h}$. Here, time $\mathrm{x}$ represents any time point, and time 0 represents the $1 \mathrm{X}$ expression of the target gene in the untreated cells normalized to gapdh.

\subsection{Statistics}

For statistical analysis, mean values \pm SEM were calculated from the result of three independent experiments performed and presented in graphs. A one-way ANOVA was used to obtain significance (P value). ${ }^{*}$ indicates differences between indicated groups considered significant at $p<0.05$.

Author Contributions: Conceptualization, H.-S.L., methodology, H.-S.L. and G.-S.J., formal and statistical analysis, H.-S.L., writing, H.-S.L. and G.-S.J., supervision, G.-S.J. All authors have read and agreed to the published version of the manuscript.

Funding: This study was funded by Basic Science Research Program through the National Research Foundation of Korea (NRF) funded by the Ministry of Education (NRF-2016R1A6A1A03011325).

Conflicts of Interest: The authors declare no conflict of interest.

\section{References}

1. Charles, A.; Janeway, J.; Travers, P.; Walport, M.; Shlomchik, M.J. T Cell-mediated immunity. In Immunobiology: The immune System in Health and Diseases; Garland Science: New York, NY, USA, 2001. Available online: https://www.ncbi.nlm.nih.gov/books/NBK10762/ (accessed on 29 October 2020).

2. Skapenko, A.; Leipe, J.; Lipsky, P.E.; Schulze-Koops, H. The role of the T cell in autoimmune inflammation. Arthritis Res. Ther. 2005, 7, S4. [CrossRef] [PubMed]

3. Pilli, D.; Zou, A.; Tea, F.; Dale, R.C.; Brilot, F. Expanding role of T cells in human autoimmune diseases of the central nervous system. Front. Immunol. 2017, 8, 1. [CrossRef] [PubMed]

4. Sugamura, K.; Asao, H.; Kondo, M.; Tanaka, N.; Ishii, N.; Nakamura, M.; Takeshita, T. The common $\gamma$-chain for multiple cytokine receptors. Adv. Immunol. 1995, 59, 225-277. [PubMed] 
5. Shi, M.; Lin, T.H.; Appell, K.C.; Berg, L.J. Cell Cycle Progression following Naive T Cell Activation Is Independent of Jak3/Common $\gamma$-Chain Cytokine Signals. J. Immunol. 2009, 183, 4493-4501. [CrossRef]

6. Ohtsuka, S.; Ogawa, S.; Wakamatsu, E.; Abe, R. Cell cycle arrest caused by MEK/ERK signaling is a mechanism for suppressing growth of antigen-hyperstimulated effector T cells. Int. Immunol. 2016, 28, 547-557. [CrossRef] [PubMed]

7. Sherr, C.J. G1 phase progression: Cycling on cue. Cell 1994, 79, 551-555. [CrossRef]

8. Robb, R.J.; Lin, Y. T-Cell Growth Factor. In Thymic Hormones and Lymphokines; Springer: Boston, MA, USA, 1984; pp. 247-256.

9. Morgan, D.A.; Ruscetti, F.W.; Gallo, R. Selective in vitro growth of T lymphocytes from normal human bone marrows. Science 1976, 193, 1007-1008. [CrossRef]

10. Depper, J.M.; Leonard, W.J.; Robb, R.J.; Waldmann, T.A.; Greene, W.C. Blockade of the interleukin-2 receptor by anti-Tac antibody: Inhibition of human lymphocyte activation. J. Immunol. 1983, 131, 690-696.

11. Wedel, J.; Hottenrott, M.C.; Stamellou, E.; Breedijk, A.; Tsagogiorgas, C.; Hillebrands, J.-L.; Yard, B.A. N-Octanoyl dopamine transiently inhibits $\mathrm{T}$ cell proliferation via G1 cell-cycle arrest and inhibition of redox-dependent transcription factors. J. Leukoc. Biol. 2014, 96, 453-462. [CrossRef]

12. Berges, C.; Haberstock, H.; Fuchs, D.; Miltz, M.; Sadeghi, M.; Opelz, G.; Daniel, V.; Naujokat, C. Proteasome inhibition suppresses essential immune functions of human CD4 + T cells. Immunology 2008, 124, 234-246. [CrossRef]

13. Feling, R.H.; Buchanan, G.O.; Mincer, T.J.; Kauffman, C.A.; Jensen, P.R.; Fenical, W. Salinosporamide A: A highly cytotoxic proteasome inhibitor from a novel microbial source, a marine bacterium of the new genus Salinospora. Angew. Chem. Int. Ed. 2003, 42, 355-357. [CrossRef]

14. Harer, S.L.; Bhatia, M.S.; Bhatia, N.M. Proteasome inhibitors mechanism; Source for design of newer therapeutic agents. J. Antibiot. (Tokyo) 2012, 65, 279-288. [CrossRef] [PubMed]

15. Fribley, A.; Wang, C.Y. Proteasome inhibitor induces apoptosis through induction of endoplasmic reticulum stress. Cancer Biol. Ther. 2006, 5, 745-748. [CrossRef] [PubMed]

16. Guo, N.; Peng, Z. MG132, a proteasome inhibitor, induces apoptosis in tumor cells. Asia. Pac. J. Clin. Oncol. 2013, 9, 6-11. [CrossRef] [PubMed]

17. Laphanuwat, P.; Jirawatnotai, S. Immunomodulatory Roles of Cell Cycle Regulators. Front. Cell Dev. Biol. 2019, 7, 23.

18. Paul, S.; Schaefer, B.C. A new look at T cell receptor signaling to nuclear factor-кB. Trends Immunol. 2013, 34, 269-281. [CrossRef] [PubMed]

19. Wu, J.; Wang, X.; Luo, H.; Chen, H.; Duguid, W. Proliferation Role of Proteasomes in T Cell Activation and proliferation. J. Immunol. 1998, 160, 788-801.

20. Seufert, W.; Futcher, B.; Jentsch, S. Role of a ubiquitin-conjugating enzyme in degradation of S- and M-phase cyclins. Nature 1995, 373, 78-81. [CrossRef]

21. Pagano, M.; Tam, S.W.; Theodoras, A.M.; Beer-Romero, P.; Del Sal, G.; Chau, V.; Yew, P.R.; Draetta, G.F.; Rolfe, M. Role of the ubiquitin-proteasome pathway in regulating abundance of the cyclin-dependent kinase inhibitor p27. Science 1995, 269, 682-685. [CrossRef]

22. Widjaja, C.E.; Olvera, J.G.; Metz, P.J.; Phan, A.T.; Savas, J.N.; De Bruin, G.; Leestemaker, Y.; Berkers, C.R.; De Jong, A.; Florea, B.I.; et al. Proteasome activity regulates CD8+ T lymphocyte metabolism and fate specification. J. Clin. Investig. 2017, 127, 3609-3623. [CrossRef]

23. Moran, E.; Carbone, F.; Augusti, V.; Patrone, F.; Ballestrero, A.; Nencioni, A. Proteasome Inhibitors as Immunosuppressants: Biological Rationale and Clinical Experience. Semin. Hematol. 2012, 49, 270-276. [CrossRef] [PubMed]

24. Hideshima, T.; Richardson, P.; Chauhan, D.; Palombella, V.J.; Elliott, P.J.; Adams, J.; Anderson, K.C. The Proteasome Inhibitor PS-341 Inhibits Growth, Induces Apoptosis, and Overcomes Drug Resistance in Human Multiple Myeloma Cells. Cancer Res. 2001, 61, 3071-3076. [PubMed]

25. Palombella, V.J.; Rando, O.J.; Goldberg, A.L.; Maniatis, T. The ubiquitinproteasome pathway is required for processing the NF- $\mathrm{BB} 1$ precursor protein and the activation of NF- $\kappa$ B. Cell 1994, 78, 773-785. [CrossRef]

26. Lee, J.; Kim, B.S.; Park, Y.; Lee, J.G.; Lim, B.J.; Jeong, H.J.; Kim, Y.S.; Huh, K.H. The effect of bortezomib on antibody-mediated rejection after kidney transplantation. Yonsei Med. J. 2015, 56, 1638-1642. [CrossRef] [PubMed] 
27. Verbrugge, E.E.; Scheper, R.J.; Lems, W.F.; de Gruijl, T.D.; Jansen, G. Proteasome inhibitors as experimental therapeutics of autoimmune diseases. Arthr. Res. Ther. 2015, 17, 1-10. [CrossRef]

28. Sun, K.; Welniak, L.A.; Panoskaltsis-Mortari, A.; O'Shaughnessy, M.J.; Liu, H.; Barao, I.; Riordan, W.; Sitcheran, R.; Wysocki, C.; Serody, J.S.; et al. Inhibition of acute graft-versus-host disease with retention of graft-versus-tumor effects by the proteasome inhibitior bortezomib. Proc. Nat. Acad. Sci. USA 2004, 101, 8120-8125. [CrossRef]

29. Vodanovic-Jankovic, S.; Hari, P.; Jacobs, P.; Komorowski, R.; Drobyski, W.R. NF-kB as a target for the prevention of graft-versus-host disease: Comparative efficacy of bortezomib and PS-1145. Blood 2006, 107, 827-834. [CrossRef]

30. Lee, H.S.; Jeong, G.S. Chrysophanol mitigates T cell activation by regulating the expression of CD40 ligand in activated T cells. Int. J. Mol. Sci. 2020, 21, 6122. [CrossRef]

Sample Availability: Samples of the compounds are not available from the authors.

Publisher's Note: MDPI stays neutral with regard to jurisdictional claims in published maps and institutional affiliations.

(C) 2020 by the authors. Licensee MDPI, Basel, Switzerland. This article is an open access article distributed under the terms and conditions of the Creative Commons Attribution (CC BY) license (http://creativecommons.org/licenses/by/4.0/). 